\title{
Two new species of Ischalia Pascoe, 1860 from China, with observations on previously described Chinese species and notes on mimicry in the Palaearctic and Nearctic members of the genus (Coleoptera: Ischaliidae)
}

\section{Ава новых вида Ischalia Pascoe, 1860 из Китая, с замечаниями по ранее описанным китайским видам и заметкой по мимикрии палеарктических и неарктических представителей рода (Coleoptera: Ischaliidae)}

\author{
Sergey V. Kazantsev ${ }^{1}$ \& Daniel K. Young ${ }^{2}$ \\ C.В. Казанцев ${ }^{1}$, Аэниэл К. Янг ${ }^{2}$
}

\author{
${ }^{1}$ Insect Centre, Donetskaya 13-326, Moscow 109651, Russia. \\ ${ }^{1}$ Инсект-центр, ул. Донецкая 13-326, Москва, 109651, Россия. E-mail: kazantss@mail.ru \\ ${ }^{2}$ Department ofEntomology, 1630 Linden Drive, University of Wisconsin, Madison, Wisconsin,53706 USA. E-mail: young@entomology.wisc.edu
}

KEY WORDS: Coleoptera, Ischaliidae, Lycidae, Omalisidae, Endomychidae, new species, mimicry, Palaearctic, Nearctic.

КЛЮЧЕВЫЕ СЛОВА: Coleoptera, Ischaliidae, Lycidae, Omalisidae, Endomychidae, новые виды, мимикрия, Палеарктика, Неарктика.

ABSTRACT. Two new species of false fire-colored beetles, Ischalia (Ischalia) anhuiensis and I. (I.) lama Kazantsev et Young, 2011 spp.n., are described from China. The male of I. (Eupleurida) sichuanensis Young, 2008 is illustrated. The hypothetic mimicry assemblages that Palaearctic and Nearctic Ischaliidae are part of are discussed.

РЕЗЮМЕ. Из Китая описывается два новых вида жуков-ложноогнецветок, Ischalia (Ischalia) anhuiensis и I. (I.) lama Kazantsev et Young, 2011 spp.n. Приводится иллюстрация самца I. (Eupleurida) sichuanensis Young, 2008. Обсуждаются комплексы мимикрии, вероятными членами которых являются палеарктические и неарктические Ischaliidae.

\section{Introduction}

The family Ischaliidae, or false fire-colored beetles, erected to accommodate the single genus, Ischalia Pascoe, 1860 , is distributed in the Holarctic (Eastern Palaearctic and Nearctic) and Indo-Malayan biogeographical regions [Gusakov \& Telnov, 2007; Young, 2008]. The three Nearctic species and two species from central China form the subgenus Eupleurida LeConte, 1862, all the others (over thirty) belong to the nominate Ischalia [Young, 2008].

The opportunity to examine Palaearctic and Nearctic representatives of this family allows us to describe two new species from China and to illustrate the previously unknown male of one of the described Chinese species,

Printed in 2011.
I. (Eupleurida) sichuanensis Young, 2008, as well as to discuss the two mimetic assemblages of which Palaearctic and Nearctic Ischalia species appear to be part.

The following acronyms are used in this paper: $\mathrm{BMNH}$ - Museum of Natural History, London; DYCM - Daniel Young Collection, Madison; ICCM Insect Center Collection, Moscow; MPGU - Moscow Pedagogical State University, Moscow; ZMMU — Zoological Museum of Moscow University, Moscow.

\section{Taxonomy}

Ischalia (Ischalia) anhuiensis Kazantsev et Young sp.n. (Figs 1, 9-10)

MATERIAL. Holotype, O’, China, Anhui, Jiuhua Shan, 7001000 m, 15-19.V.1998, S. Kazantsev leg. (ICCM).

DESCRIPTION. Male. Black; pronotal sides narrowly reddish testaceous; elytra, except sutural stripe, ochre (Fig. 1).

Head transverse, posteriorly steeply rounded to narrow parallel-sided neck. Eyes small, ca. twice as long as wide, conspicuously emarginate at inner border. Clypeus transverse, ca. 2 times wider than long, almost rectangular. Labrum transverse, rounded. Terminal segment of labial and maxillary palps bulbous, strongly securiform. Antennae filiform, extending to mid-length of elytra, with antennomere 3 twice as long as antennomere 2 and 1.2 times shorter than antennomere 4 (Fig. 1).

Pronotum transverse, 1.5 times wider than long, conspicuously narrowed and slightly concave anteriorly, convex at sides, with noticeable anterior and acute laterally produced posterior angles; medially with narrow carina in posterior four fifths and narrow groove in anterior fifth; two pairs of pores located in transverse depression in posterior third (Fig. 1). 
Elytra subglabrous, moderately long, ca. 2.5 times longer than wide at humeri, parallel-sided, flattened, with lateral costa nearly reaching apex and humeral costa extending to elytral third; surface densely punctate; lateral interstice with five rows of punctures; pubescence very short and decumbent (Fig. 1). Metathoracic wings fully developed.

Abdomen with six ventrites; first ventrite with median intercoxal carina in proximal two thirds, fifth ventrite broadly, shallowly emarginate. Legs with almost straight femora and conspicuously widened tarsomeres.

Aedeagus almost parallel-sided and relatively broad, with median lobe gradually narrowing distally; invaginated tergite with relatively broad proximal portion (Figs 9-10).

Length: $7.6 \mathrm{~mm}$. Width (humerally): $2.3 \mathrm{~mm}$.

Female. Unknown.

ETYMOLOGY. The name of the new species is derived from the province in southeast China where the unique type specimen was collected.
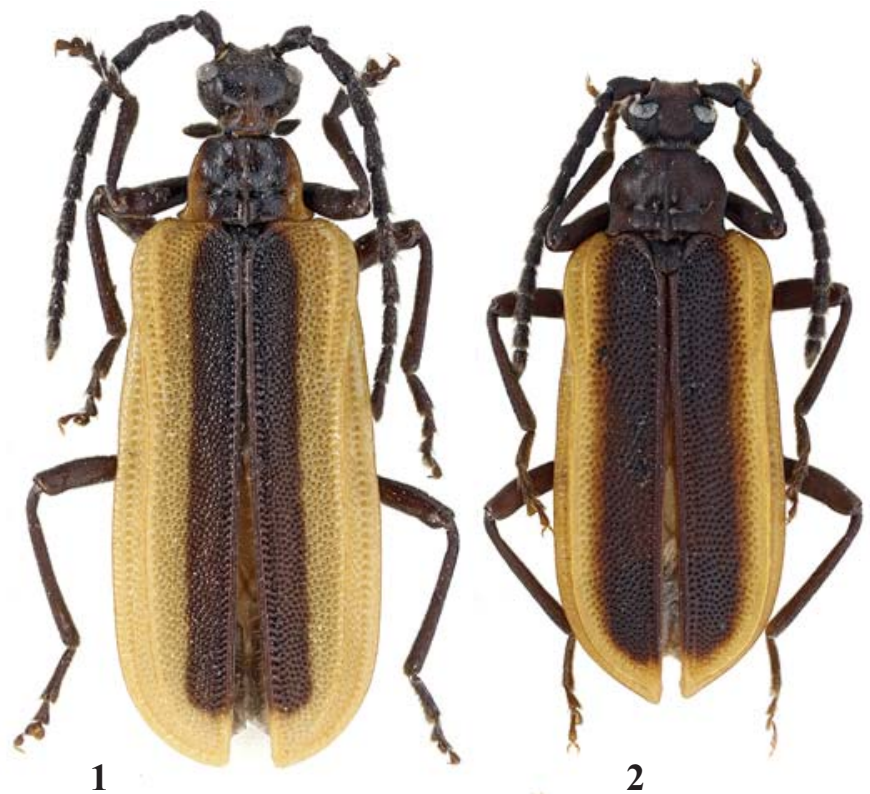

2

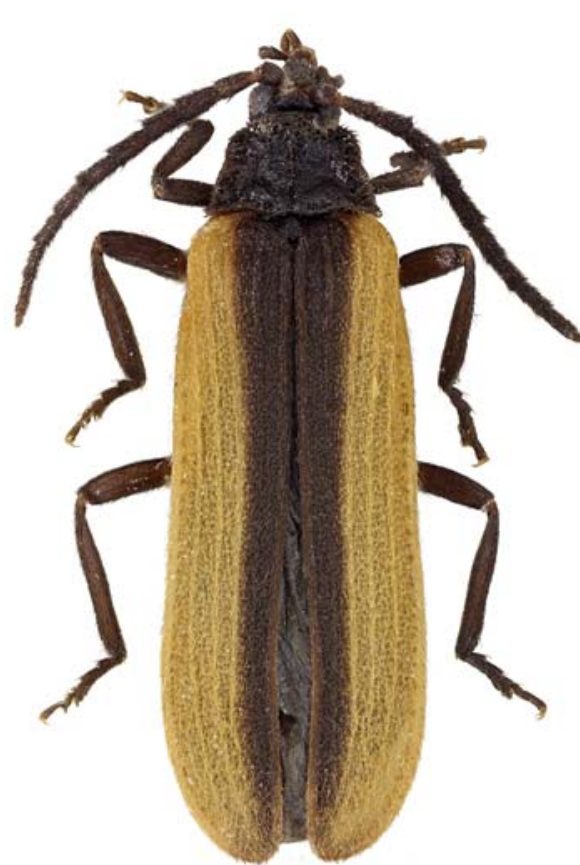

4

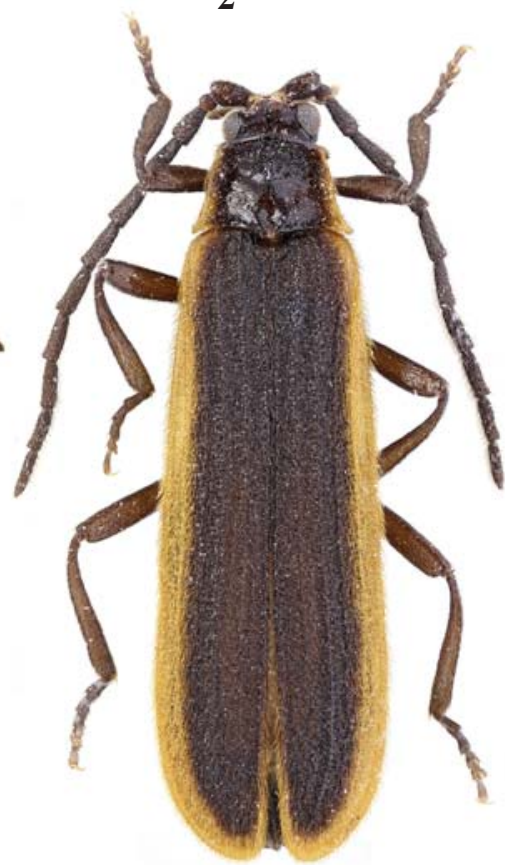

5

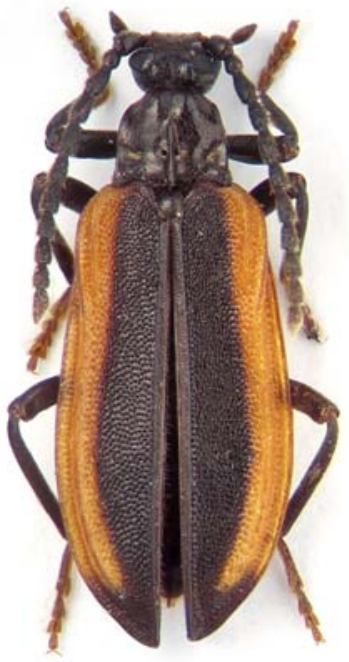

3

Figs 1-6. General view of Ischaliidae, Lycidae and Omalisidae: 1 - Ischalia anhuiensis sp.n. $(1=7.6 \mathrm{~mm}) ; 2-$ I. lama sp.n. $(1=6.5$ $\mathrm{mm}) ; 3$ - I. brachyptera $(1=6.7 \mathrm{~mm}) ; 4$ - Libnetis piceovittatus $(1=6.1 \mathrm{~mm}) ; 5$ - Libnetisia latruncula $(1=6.8 \mathrm{~mm}) ; 6$ - Omalisus fontisbellaquaei $(1=7.2 \mathrm{~mm}) ; 1-2$ - holotypes; 5 - paratype.

Рис. 1-6. Общий вид Ischaliidae, Lycidae и Omalisidae: 1 - Ischalia anhuiensis sp.n. $(1=7.6$ мм); 2 - I. lama sp.n. $(1=6.5$ мм $)$; 3 -I. brachyptera $(1=6.7 \mathrm{~mm}) ; 4$ - Libnetis piceovittatus $(1=6.1 \mathrm{Mм}) ; 5$ - Libnetisia latruncula $(1=6.8 \mathrm{Mm}) ; 6$-Omalisus fontisbellaquaei $(1=7.2$ мм); $1-2$ - голотипы; 5 - паратип. 
DIAGNOSIS. Ischalia anhuiensis sp.n. differs from all congenerics by the combination of rufous pronotal sides, laterally produced posterior pronotal angles and relatively narrow dark elytral sutural stripe (Fig. 1), as well as by the relatively broad proximal portion of the invaginated tergite and relatively broad aedeagus ( Figs 15-16).

\section{Ischalia (Ischalia) lama Kazantsev et Young sp.n.} (Figs 2, 11)

MATERIAL. Holotype, $\sigma^{7}$, China, C Sichuan, Xiling Snow Mts, 1300-2100 m, 7-10.VII.1999, S. and I. Kazantsev leg. (ICCM).

DESCRIPTION. Male. Black; elytra, except sutural stripe, ochre (Fig. 2).

Head transverse, posteriorly steeply rounded to narrow parallel-sided neck. Eyes relatively large, extending mediad to edge of antennal socket, deeply emarginate at inner border. Clypeus transverse, ca. 2 times wider than long, almost rectangular. Labrum transverse, rounded. Terminal segment of labial and maxillary palps large, bulbous, strongly securiform. Antennae filiform, extending to elytral two fifths, with antennomere 3 twice as long as antennomere 2 and 1.2 times longer than antennomere 4 (Fig. 2).

Pronotum transverse, 1.25 times wider than long, rounded anteriorly and slightly emarginate medially, convex laterally, with small acute posterior angles; medially with drop-like bulbous process in posterior fifth, narrow carina in three middle fifths and narrow groove in anterior fifth; two pairs of pores located in transverse depression in posterior fourth (Fig. 2).

Elytra matt, moderately long, ca. 2.3 times longer than wide at humeri, parallel-sided, flattened, with lateral costa fused with suture near apex, humeral costa extending to elytral fourth; surface densely punctate; lateral interstice with three rows of punctures (four rows in distal fourth); pubescence very short, sparse and decumbent (Fig. 2). Metathoracic wings fully developed.

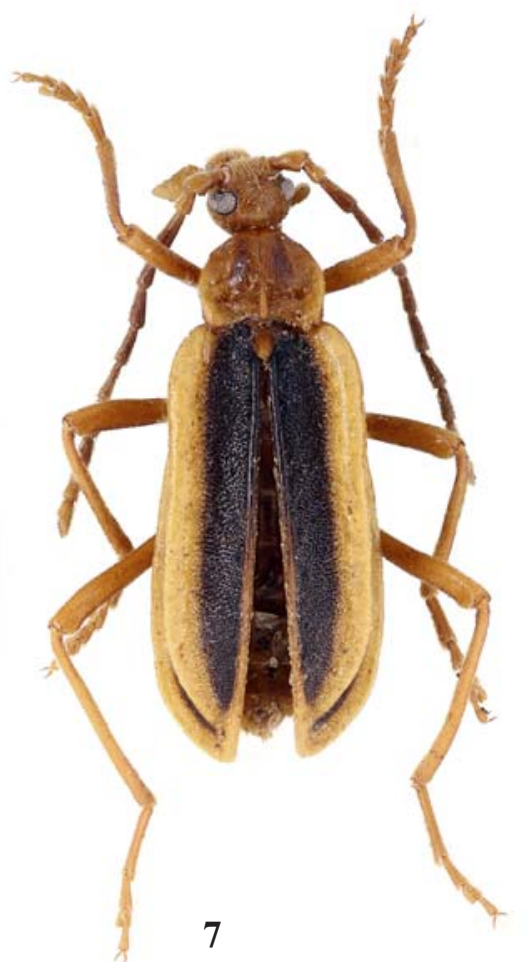

Abdomen with six ventrites; first ventrite with short median intercoxal carina, fifth ventrite shallowly emarginate. Legs with almost straight femora and conspicuously widened tarsomeres.

Aedeagus narrowing distally, with slightly emarginate, distally fused parameres; invaginated tergite with constricted proximal portion and triangularly widened distal processes (Fig. 11).

Length: $6.5 \mathrm{~mm}$. Width (humerally): $2.2 \mathrm{~mm}$.

Female. Unknown.

ETYMOLOGY. The name of the new species is derived from "lama", a frequent personage of Tibet, from the easternmost foothills where the unique type specimen originates.

DIAGNOSIS. Ischalia lama sp.n. resembles I. chinensis Young, 1975 by the coloration and shape of pronotum, differing by the bulbous terminal segment of maxillary palps and only slightly emarginate, distally fused parameres (Fig. 11).

Ischalia (Ischalia) brachyptera Nikitsky, 1994 (Figs 3, 12-14)

Ischalia (Ischalia) brachyptera Nikitsky, 1994: 35

MATERIAL. +, FE Russia, S Primorje, Hasan distr., R. Kedrovaya, 25-30.V.1990, S. Kazantsev leg.; $5 O^{7} O^{7}$ and 5 우, FE

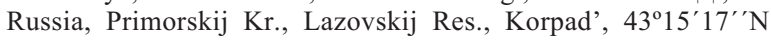
$134^{\circ} 08^{\prime} \mathrm{E}, 17-18 . \mathrm{VI} .2005$, K. Makarov leg. (ICCM and MPGU).

REMARKS. A small series of Ischalia brachyptera collected in the Lazovskij Reserve (Primorskij Kraj, Far East Russia) by Kirill Makarov allows illustrating some of the morphological characters of the species in more detail, with a $\mathrm{KOH}$ cleared female specimen at hand. The pronotum is divided by a complete median suture and has two pairs of pores, the larger and elongate ones in close proximity to median rib (Fig. 12). The mesothoracic episternum is fused with the epimeron, the resultant sclerites nearly contiguous ventrally, each with three superficial transverse folds; the metaventrite lacks a discrimen (Fig. 13). The metendosternite is transverse, with a pair of long lateral arms (Fig. 14).

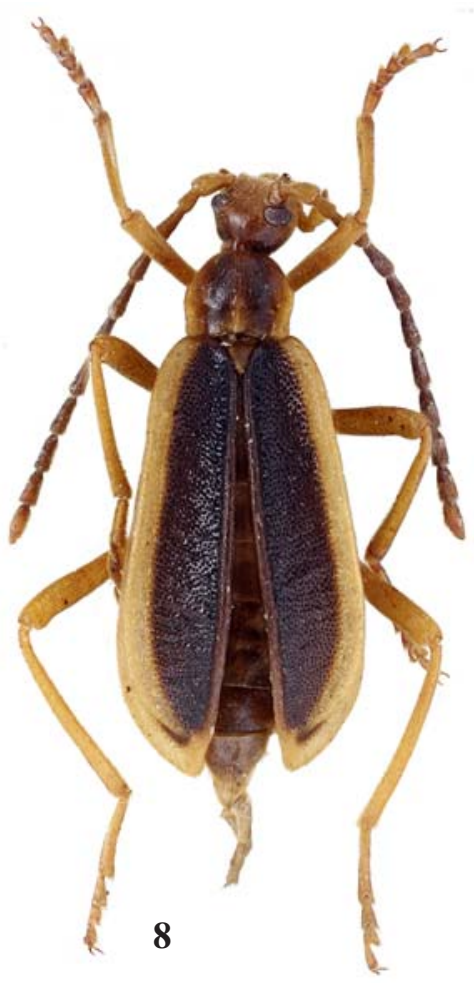

Figs 7-8. General view of Ischalia sichuanensis; 7 - male $(1=6.5 \mathrm{~mm}) ; 8$ - female $(1=6.6 \mathrm{~mm})$.

Рис. 7-8. Общий вид Ischalia sichuanensis; 7 - самец $(1=6.5$ мм $) ; 8$ - самка $(1=6.6$ мм $)$. 
Ischalia (Eupleurida) aptera Gusakov et Telnov, 2007

Ischalia (Eupleurida) aptera Gusakov et Telnov, 2007: 40 MATERIAL. $\sigma^{7}$, Holotype, China, N Sichuan, Minshan Mts, pass Nanping-Pingwu, $3500 \mathrm{~m}$, pitfall trap, 1-10.VII.2005, V. Patrikeev leg. (ZMMU); + , paratype, same label as holotype (ZMMU); +. China, N Sichuan, pass Nanping-Songpan, 3450-3500 m, 22.VI.2002, S. Murzin leg. (ICCM).

REMARKS. Although quite similar to Ischalia sichuanensis in many aspects, I. aptera may be easily differentiated from it by the parallel-sided elytra in both sexes.

Ischalia (Eupleurida) sichuanensis Young, 2008 (Figs 7-8)

Ischalia (Eupleurida) sichuanensis Young, 2008: 326

MATERIAL. + (paratype), China, Sichuan, E pass btw Zhangla-Juizhaigou, 3500 m, 8-11.VI.2001, S. Murzin leg. (ICCM); O" $^{7}$ China, S Gansu, Tepo (Tewo), 2500-2800 m, 26-28.VI.2001, S Kazantsev leg. (ICCM); 9 , China, C Sichuan, Xilingxue Mts, 100 km W Chengdu, 2400-3200 m, 29-31.VII.2001, S. Kazantsev leg. (ICCM); 3 우 (incl. Holotype and paratype), China, Sichuan, pass
Nanping-Songpan, 3100 m, 26.VI.2002, A. Gorodinsky leg. (BMNH, DYCM and ICCM)

REMARKS. Unlike the rest of its congenerics, I. sichuanensis has marked secondary sexual dimorphism, with almost parallel-sided elytra in males and oval elytra in females (Figs 7-8).

\section{Mimicry}

There is a remarkable phenomenon relating to the Holarctic members of the genus Ischalia: each of its Palaearctic and Nearctic groups is characterized by a common color pattern: ochre elytra with a relatively broad dark brown sutural stripe in the Palaearctic species (e.g., Figs 1-3, 7-8), and mostly dark brown elytra with ochre humeral markings, characteristic of the Nearctic species (Figs 15-17). Apparently, in these two vast areas the false fire-colored beetles, whose palatability is unknown, are elements of mimicry complexes.

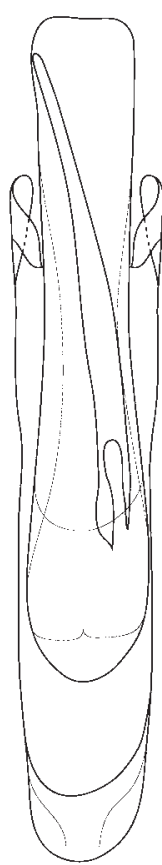

9

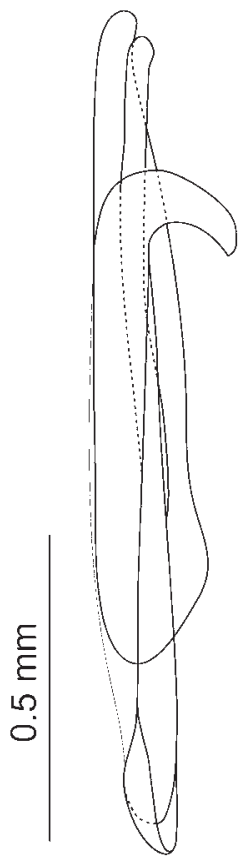

10

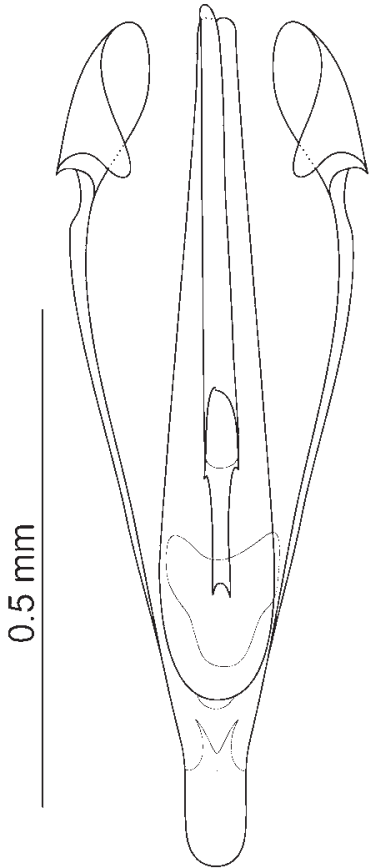

11

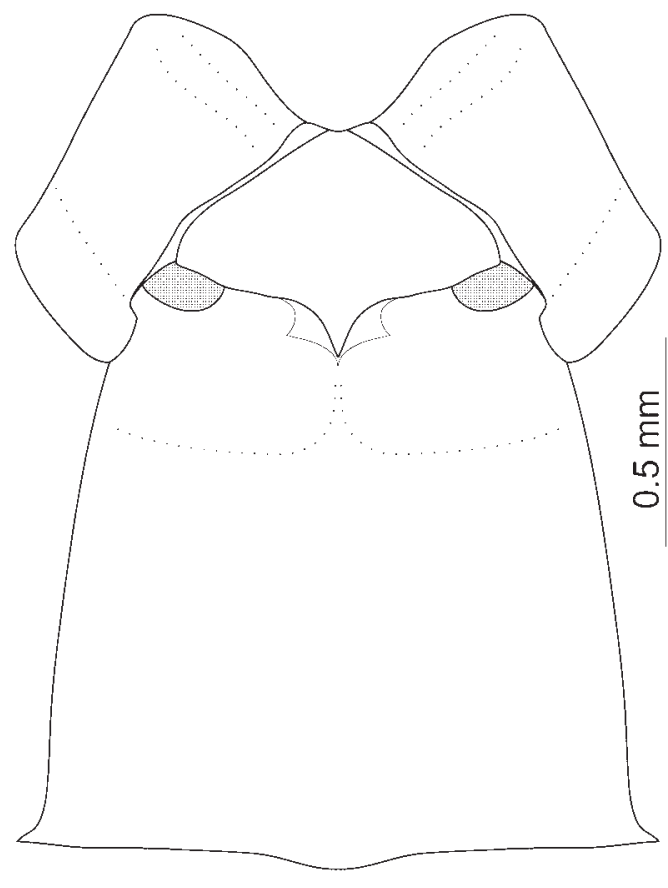

13
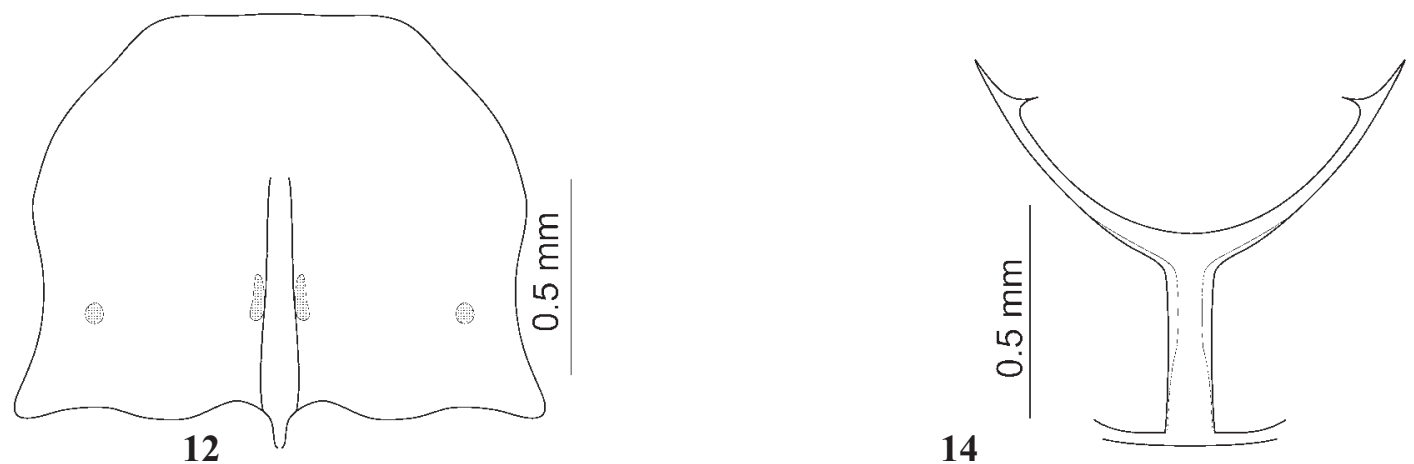

Figs 9-14. Details of Ischaliidae: 9-10 - Ischalia anhuiensis sp.n.; 11 - I. lama sp.n.; 12-14 - I. brachyptera; 9-11 - aedeagus; 12 - pronotum; 13 - meso- and metaventrite; 14 - metendosternite; $9,11,13$ - ventral view; $12,14-$ dorsal view; $10-$ lateral view.

Рис. 9-14. Детали строения Ischaliidae: 9-10 - Ischalia anhuiensis sp.n.; 11 - I. lama sp.n.; 12-14 - I. brachyptera; 9-11 эдеагус; 12 - переднеспинка; 13 - мезо- и метавентрит; 14 - метэндостернит; 9, 11, 13 - снизу; $12,14-$ сверху; $10-$ сбоку. 
The most speciose insects in the south-eastern Palaearctic (i.e. where ischaliids with the mentioned coloration pattern occur) that may be hypothesized to represent members of the same mimicry assemblages are found in the family Lycidae, or net-winged beetles. The net-winged beetles are arguably the most widespread models for many Batesian and/or Müllerian mimicry complexes in the ani- mal kingdom and are mimicked by representatives of almost every insect order, while predators, vertebrate and invertebrate alike, avoid taking lycids as prey [Carpenter \& Ford, 1933; Linsley et al., 1961]. The Lycidae were recently shown to contain at least two potent compounds, lycidic acid and pyrazines, that serve to forestall predatory attacks [Eisner et al., 2008]. The mode of life of false fire-colored

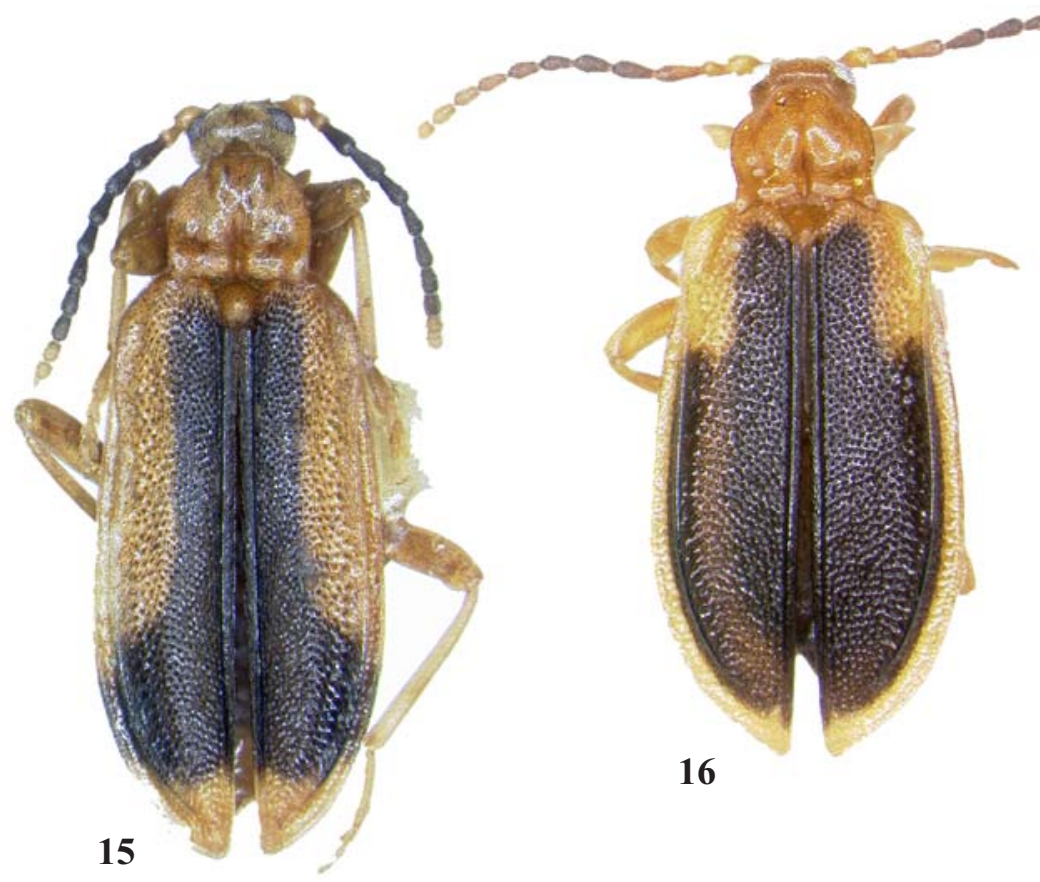

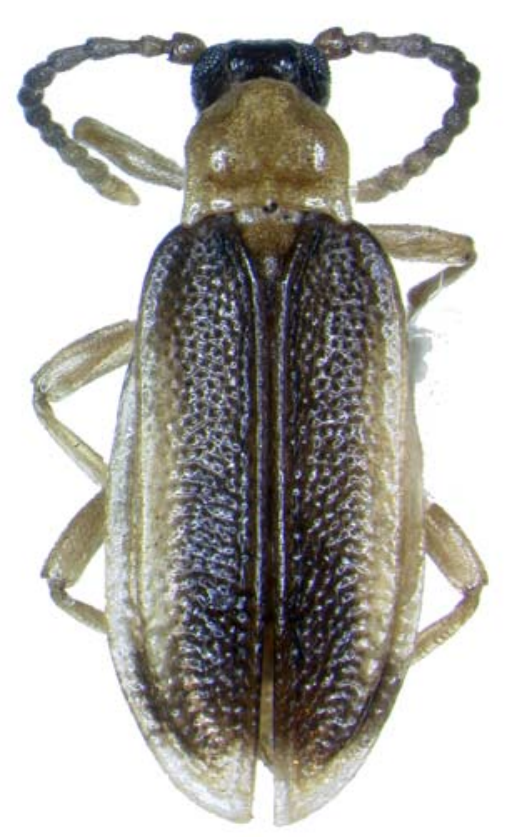

17
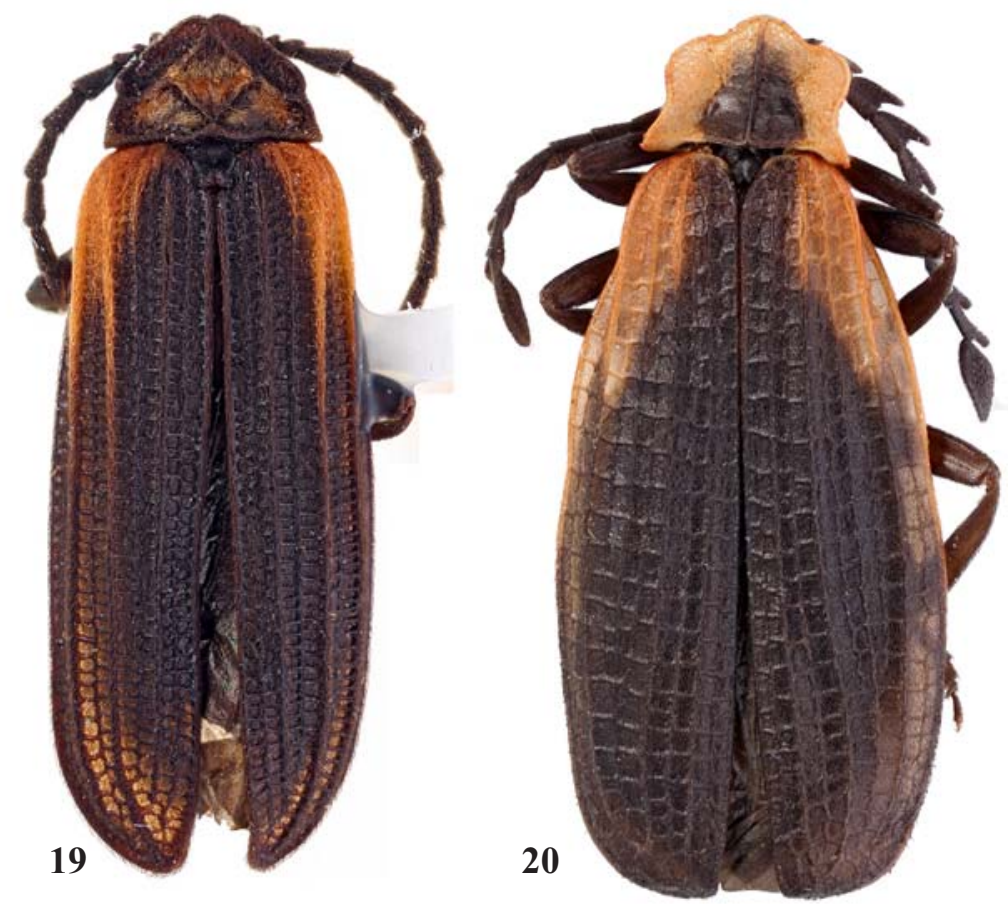

Figs 15-20. General view of Ischaliidae, Lycidae and Endomychidae: 15 - Ischalia californica $(l=5.6 \mathrm{~mm}) ; 16-I$. vancouverensis $(l=6.2 \mathrm{~mm}) ; 17-I$. costata $(l=3.6 \mathrm{~mm}) ; 18-$ Aphorista laeta $(l=6.2 \mathrm{~mm}) ; 19-$ Greenarus thoracicus $(l=9.7 \mathrm{~mm}) ; 20-C a e n i a$ amplicornis $(1=8.3 \mathrm{~mm})$.

Рис. 15-20. Общий вид Ischaliidae, Lycidae и Endomychidae: 15 - Ischalia californica $(l=5.6 \mathrm{~mm}) ; 16$ - I. vancouverensis $(l=6.2 \mathrm{~mm})$; 17 - I. costata $(l=3.6 \mathrm{~mm}) ; 18-$ Aphorista laeta $(l=6.2 \mathrm{~mm}) ; 19-$ Greenarus thoracicus $(l=9.7 \mathrm{~mm}) ; 20-C a e n i a$ amplicornis $(l=8.3 \mathrm{~mm})$. 
beetles, according to Van Dyke [1938], Young [1985], Makarov (pers. communication) and authors' personal field observations, is fairly similar to that of Lycidae and supports our hypothesis that they form mimetic assemblages with lycids. Known larvae of Ischaliidae, just as their lycid counterparts, are slow moving and found in association with fungal growth on decaying logs, their adults observed in the same places or on nearby low-strata vegetation. As is the case with Lycidae, ischaliid larvae do not seem to be trophically linked to any particular group of trees, but rather to any rotten wood (e.g., oaks or pines) already to high degree decayed.

Certain south-eastern Palaearctic representatives of several lycid genera, e.g., Libnetis piceovittatus Kazantsev, 1992 (Fig. 4), Dihammatus brancuccii Kazantsev, 1992 from the Himalayas or Libnetisia latruncula (Kazantsev, 2000) (Fig. 5) from China, display color patterns virtually identical to regional ischaliids. Some other local lycids, such as the numerous Himalayan Plateros species, often have a similar pattern as well, with ochre in their elytra sometimes replaced with reddish tones. It is noteworthy that distributions of lycid and ischaliid taxa with similar color patterns quite perfectly coincide, only the false fire-colored beetles slightly more advance to the northeast, reaching the Sikhote-Alin Mountains and the Kunashir Island in the Russian Far East.

Also noteworthy is the conspicuous similarity in color patterns of Palaearctic Ischaliidae to that of Omalisus fontisbellaquaei Geoffroy, 1785 (Fig. 6), a representative of Omalisidae. The latter family is restricted to Europe, while its members are also collected only on lowstrata vegetation in shadowy forests. As the Recent fauna of a number of insect groups of the Himalayas and mountains of Central and South China, including the Lycidae, has been documented to be rather similar to that of the Baltic amber [Zherichin, 1971; Kazantsev, 1997; Grimaldi \& Engel, 2005], it cannot be ruled out that the omalisids and Palaearctic ischaliids, as well as similar looking lycids, are remnants of a mimetic assemblage that dates back to approximately 50 million years ago.

In North America, a plausible mimicry web may also be proposed between the three Nearctic species of Ischalia, I. californica Van Dyke, 1938 (Fig. 15), I. vancouverensis Harrington, 1892 (Fig. 16) and I. costata (LeConte, 1862) (Fig. 17), on the one hand, and the lycids Eros humeralis (Fabricius, 1801), Greenarus thoracicus (Randall, 1838), (Fig. 19) Leptoceletes basalis (LeConte, 1847) or Caenia amplicornis LeConte, 1882 (Fig. 20), on the other. However, an even more striking case can be found amongst Ischalia and the eumorphine endomychid genus, Aphorista Gorham, 1873. Baiting filter paper disks with the terpenoid compound, cantharidin, Young [1984] reported attracting the aposematically colored $A$. laeta (LeConte, 1854) (Fig. 18) in California and Idaho, as well as $A$. vittata (Fabricius, 1787) in Michigan. He speculated one scenario in which cantharidin might,,mimic" a fungal metabolite used by the endomychids to locate a suitable fungal host. As is commonly known from the plant-insect interaction literature, fungal compounds might be sequestered by the Endomychidae during feeding, affording them protection from predators. It has been noted [e.g., Skelley \& Leschen, 2002] that some handsome fungus beetles exhibit reflex bleeding. However, the specific nature of such mimicry complexes, i.e., Batesian, Müllerian, or both, remains undisclosed here [e.g., Shockley et al., 2009, and refereneces cited therein].

In Wisconsin, Price and Young [2008] used a jar trap baited with filter paper for surveying Endomychidae. Of the 226 specimens of $A$. vittata examined during the survey, 222 were taken at cantharidin. The same traps also attracted specimens of $I$. costata. In Idaho, specimens of both $A$. laeta and $I$. vancouverensis were recovered from the same cantharidin-baited jar traps on the same day. Like the sluggish false fire-colored (and netwinged) beetles the mimic Nearctic endomychids generally move slowly on or through the substrate and are flightless, just as all three Nearctic ischaliids.

ACKNOWLEDGEMENTS. It is our pleasant duty to express gratitude to Dr. A.A. Gusakov (Moscow) for the possibility to study the types of Ischalia aptera from the collection under his care and to Prof. K.V. Makarov (Moscow) for sharing material and information on Ischalia brachyptera habitats and habits and for the assistance with the color photographing.

\section{References}

Carpenter G.D.H. \& Ford E.B. 1933. Mimicry. London. viii + $133 \mathrm{p}$.

Eisner Th., Schroeder F.C., Snyder N., Grant J.B., Aneshansley D.J., Utterback D., Meinwald J. \& Eisner M. 2008. Defensive chemistry of lycid beetles and of mimetic cerambycid beetles that feed on them // Chemoecology. Vol.18. No.2. P.109-119.

Grimaldi D. \& Engel M.S. 2005. Evolution of the Insects. Cambridge: University Press. 755 pp.

Gusakov A. \& Telnov D. 2007. Systematic changes and new species of Ischaliidae (Coleoptera) // Folia Heyrovskyana, Series A. Vol.15. No.1. P.39-46.

Kazantsev S.V. 1997. A recent species of the fossil genus Kolibaceum Winkler (Coleoptera, Lycidae) from Eastern China // Entomologica Basiliensia. Vol.20. P.159-164.

Linsley E.G., Eisner Th. \& Klots A.B. 1961. Mimetic assemblages of sibling species of lycid beetles // Evolution. Vol.15. No.1. P.15-29.

Price M.B. \& Young D.K. 2008. An annotated checklist of Wisconsin handsome fungus beetles (Coleoptera: Endomychidae) // Great Lakes Entomologist. Vol.40 (2007). P.177-188.

Shockley F.W., Tomaszewska K.W. \& McHugh J.V. 2009. Review of the natural history of the handsome fungus Beetles (Coleoptera: Cucujoidea: Endomychidae) // Insecta Mundi. Vol.72. P.1-24.

Skelley P.E. \& Leschen R.A.B. 2002. 92. Family Endomychidae // R.H.Jr. Arnett \& M.C. Thomas (eds). American Beetles. Boca Raton: St. Lucie Press. P.366-370.

Van Dyke E.C. 1938. New species of Pacific Coast Coleoptera (Cleridae, Pyrochroidae, Chrysomelidae)//Entomological News. Vol.49. P.189-195.

Young D.K. 1976. A new species of Ischalia from southeastern China (Coleoptera: Pyrochroidae) // The Pan-Pacific Entomologist. Vol.52. P.213-215.

Young D. K. 1984. Field records and observations of insects associated with canthari-din // Great Lakes Entomologist. Vol.17. P.195-199.

Young D.K. 1985. Description of the larva of Ischalia vancouverensis Harrington (Coleoptera: Anthicidae: Ischaliinae), with observation on systematic position of the genus // The Coleopterists Bulletin. Vol.39. P.201-206.

Young D.K. 2008. Three new Asian species of Ischalia Pascoe, 1860 (Coleoptera: Ischaliidae), with a world checklist of subgenera and species // The Pan-Pacific Entomologist. Vol.83. No.4 (2007). P.321-331.

Zherichin V.V. 1971. The zoogeographical relationships of Baltic amber Rhynchophora (excluding Scolytidae) // Papers of the XIIIth International Entomological Congress. Vol.1. Leningrad: Nauka. P.322-323. 